Volume. 7 Nomor. 1, Oktober 2019. p - 2354-8649 I e - 2579-5767 Open Access at: http://ojs.umrah.ac.id/index.php/selat DOI: https://doi.org/10.31629/selat.v7i1.1451

\title{
DETERMINASI PERLINDUNGAN HUKUM PEMEGANG HAK TERKAIT DALAM UNDANG-UNDANG REPUBLIK INDONESIA NOMOR 28 TAHUN 2014 TENTANG HAK CIPTA
}

\author{
Afrizal Musdah Eka Putra \\ Magister Ilmu Hukum Universitas Padjadjaran \\ Jl. Banda No. 42 Bandung 40132 \\ Email : afrizal18001@mail.unpad.ac.id
}

\begin{abstract}
Related Rights are rights relating to Copyright which are exclusive rights to those invited, phonogram producers, or broadcasters. The emergence of Copyright with Copyright in the country originated from the Copyright permission itself, because copyright is part of Copyright. In the development of globalization there are a lot of copyrighted works such as songs, films, television shows that are often misused by irresponsible people such as multiplying, marketing and helping to obtain financial benefits, so that the creator or owner of copyright can be referred to both in terms of moral rights and rights The economy. Because this is the right associated with copyright that was born with the aim of protecting the rights of the perpetrators, record producers and broadcasters from their work. Legal protection for related rights is provided through statutory regulations namely Law No. 28 of 2014 concerning Copyright as well as through international conventions, namely the Rome convention of 1961, the Geneva Conventions, and the Brussels Convention.
\end{abstract}

Keyword; Copyright, Related Rights, Intellectual Property Rights.

\begin{abstract}
Abstrak
Hak Terkait adalah hak yang berkaitan dengan Hak Cipta yang merupakan hak eksklusif bagi mereka yang diundang, produser rekaman suara, atau penyiar. Munculnya Hak Cipta dengan Hak Cipta di negara tersebut berasal dari izin Hak Cipta itu sendiri, karena hak cipta adalah bagian dari Hak Cipta. Dalam perkembangan globalisasi ada banyak karya berhak cipta seperti lagu, film, acara televisi yang sering disalahgunakan oleh orang-orang yang tidak bertanggung jawab seperti mengalikan, memasarkan dan membantu mendapatkan keuntungan finansial, sehingga pencipta atau pemilik hak cipta dapat dirujuk baik dari segi hak moral dan hak-hak ekonomi. Karena ini adalah hak yang terkait dengan hak cipta yang lahir dengan tujuan melindungi hak-hak para pelaku, produsen rekaman dan penyiar dari pekerjaan mereka. Perlindungan hukum untuk hak-hak terkait disediakan melalui peraturan perundang-undangan yaitu Undang-Undang Nomor 28 Tahun 2014 tentang Hak Cipta serta melalui konvensi internasional, yaitu konvensi Roma tahun 1961, Konvensi Jenewa, dan Konvensi Brussels.
\end{abstract}

Kata Kunci; Hak Cipta, Hak Terkait, Hak Kekayaan Intelektual. 


\section{PENDAHULUAN}

Karya ilmu pengetahuan atau scientific meliputi ciptaan; buku, program komputer, pamflet, perwajahan atau lay out, karya tulis yang diterbitkan, dan semua hasil karya tulis yang lain; ceramah, pidato, dan ciptaan lain yang sejenis dengan itu; alat peraga yang dibuat untuk kepentingan pendidikan dan ilmu pengetahuan; arsitektur, dan peta. Sedangkan karya seni mencakup; lagu atau musik dengan atau tanpa teks; drama atau drama musikal, tari, koreografi, pewayangan, dan pantomim; seni rupa dalam segala bentuk seperti seni lukis, gambar, seni ukir, seni kaligrafi, seni pahat, seni patung, kolase, dan seni terapan; seni batik, fotografi, dan sinematografi. Adapun karya sastra atau literary work di antaranya adalah; terjemaahan, tafsir, saduran, bunga rampai, database dan karya lain dari hasil pengalih wujudan. Dari uraian mengenai jenis-jenis ciptaan tersebut, karya ilmu pengetahuan dan karya sastra memiliki media tertulis baik yang berupa buku, karya tulis ilmiah, seperti disertasi, tesis, skripsi dan makalah maupun yang berupa artikel untuk jurnal, buletin, majalah atau koran. ${ }^{1}$

Zaman modern merupakan zaman di mana manusia dituntut untuk mengembangkan diri. Artistik identik dengan seni, karena itulah manusia sering disebut makhluk berkesenian. Manusia dapat dikatakan sebagai makhluk yang memiliki keistimewaan. Adanya suatu keistimewaan ini melahirkan hak dari manusia tersebut untuk mendapat pengakuan, dihargai, dan dihormati. Teori yang sering muncul dalam sejarah pikiran manusia ialah bahwa keistimewaan manusia terletak dalam wujud manusia itu sendiri, sebagaimana didapati melalui pikirannya, maka keistimewaan manusia itu bersifat rasional. Hak-hak yang didapati orang secara rasional dianggap abadi dan tetap berlaku. Tiap-tiap orang lain, termasuk pemerintah harus mengindahkannya, dengan membuat hukum atas dasar hak-hak alamiah tersebut. ${ }^{2}$

Terdapat tiga jenis sistem hukum yang berlaku di Indonesia yaitu sistem hukum adat, hukum perdata dan islam. Ketiganya memiliki sistem tersendiri serta peraturan terpisah yang diatur oleh pejabat pemerintah yang berbeda dan diberlakukan dipengadilan terpisah. Perbedaan system hukum ini telah berkembang dan hidup

\footnotetext{
${ }^{1}$ Henry Soelistyo, Hak Cipta Tanpa Hak Moral, (Jakarta: PT. Raja Grafindo Persada, Jakarta, 2011), hlm. 185.

2 Maria Alfons, Implementasi Hak Kekayaan Intelektual Dalam Perspektif Negara Hukum, Jurnal legislalasi Indonesia, Vol. 14 No. 03 - September 2017, hlm. 2.
} 
berdampingan di Indonesia selama berabad-abad. ${ }^{3}$ Salah perkembangan yang harus diperhatikan adalah mengenai hukum perdata yang bertalian erat dengan Hak Kekayaan Intelektual.

Hukum Hak Kekayaan Intelektual (HKI) sendiri sebagai bentuk penghargaan atas Hak Kekayaaan Intelektual (HKI), perlindungan hukum atas hak-hak tersebut memerlukan perangkat hukum dan mekanisme perlindungan yang memadai. Melalui cara inilah HKI akan mendapat tempat yang layak sebagai salah satu bentuk hak yang memiliki nilai ekonomis. Hukum HKI adalah hukum yang mengatur perlindungan bagi para pencipta dan penemu karya-karya inovatif sehubungan dengan pemanfaatan karya-karya mereka secara luas dalam masyarakat. Karena itu tujuan hukum HKI adalah menyalurkan kreativitas individu untuk kemanfaatan manusia secara luas. ${ }^{4}$

Hak Cipta merupakan salah satu bagian dari kekayaan intelektual yang memiliki ruang lingkup mencakup ilmu pengetahuan, seni dan sastra (art and literary). Hak cipta merupakan bagian dari HKI yang terkandung hak ekonomi dan hak moral. Hak ekonomi yang dimiliki pencipta atau pemegang merupakan hak eksklusif pencipta atau pemegang hak cipta untuk mendapatkan manfaat ekonomi atas ciptaan dan hak moral dapat didefinisikan sebagai hak yang melekat secara abadi pada diri penciptanya. ${ }^{5}$

Saat ini berbagai macam bentuk karya seni dan budaya baik yang berbentuk musik/lagu maupun yang berbentuk sinematografi dapat dengan mudah dilakukan penyiaran yang dilakukan oleh organisasi penyiaran di Indonesia, namun semua kegiatan organisasi penyiaran telah diawasi dan diatur oleh Komisi Penyiaran Indonesia (KPI). Hal ini terjadi karena pada organisasi penyiaran terdapat tanggung jawab yang besar mengenai Hak Terkait maupun Hak Cipta. Hak Terkait (Neighbouring Right) dengan Hak Cipta merupakan hak eksklusif bagi Pelaku yang dapat terdiri dari artis film/telivisi, pemusik, penari, pelawak dan lain sebagainya

\footnotetext{
3 Sinta Dewi Rosadi, Cyber Law Aspek Data Privasi Menurut Hukum Internasional, Regional, dan Nasional, (Bandung: PT Refika Aditama, 2015), hlm. 91.

4 Sulasi Rongiyati, Pelindungan Hukum Hak Kekayaan Intelektual Pada Produk Ekonomi Kreatif, Negara Hukum: Vol. 9, No. 1, Juni 2018, hlm. 2

5 Edwita Ristyan, Perlindungan Hak Terkait Terhadap Karya Siaran Skysports yang Dipublikasikan Melalui Situs Internet, Skripsi pada Program Fakultas Hukum Universitas Atma Jaya Yogyakarta, (Yogyakarta: 2017), hlm. 1.
} 
untuk menyiarkan pertunjukannya. ${ }^{6}$ Yang dimaksud dengan menyiarkan termasuk menyewakan, melakukan pertunjukan umum (Public Performance), mengkomunikasikan pertunjukan langsung (Live Performance), dan mengkomunikasikan secara interaktis suatu karya rekaman suara pelaku. Selain pelaku, juga produser rekaman suara dan lembaga penyiaran mempunyai hak-hak terkait.

Undang-undang hak cipta di berbagai negara tidak saja melindungi hak pencipta atau ciptaannya tetapi juga melindungi hak orang yang mempertunjukkan atau dengan cara lain menyebarkan suatu ciptaan kepada masyarakat luas. Hak terkait adalah hak yang dilekatkan kepada apa saja yang memainkan peranan yang penting dalam penyebaran sebuah karya kepada masyarakat luas. ${ }^{7}$ Seperti hak cipta, hak terkait diakui secara otomatis tanpa prosedur tertentu. Hak terkait juga dilindungi oleh konvensi internasional, seperti Konvensi Internasional tentang Perlindungan Pelaku Pertunjukan, Produser Rekaman Suara, dan Lembaga Penyiaran (International Convention for the Protection of Performers, Producers of Phonograms and Broadcasting Organizations) dan Konvensi tentang Perlindungan Produser Rekaman Suara terhadap Perbanyakan Rekaman Suara Tanpa Izin (Convention for the Protection of Producers of Phonograms Against Unauthorized Duplication of Their Phonograms). Hak cipta dan hak terkait dilindungi sendiri-sendiri dan karena itu perlu mendapat izin terpisah untuk penggunaan masing-masing hak. ${ }^{8}$ Berdasarkan ketentuan Pasal 1 angka 5 Undang-Undang No. 28 Tahun 2014 Tentang Hak Cipta (UUHC) dapat diketahui bahwa yang dimaksud Hak Terkait adalah hak yang berkaitan dengan Hak Cipta yang merupakan hak eksklusif bagi Pelaku Pertunjukan, Produser Fonogram atau Lembaga Penyiaran. Konsep Hak Terkait (Neighbouring Right) muncul sebagai reaksi atas perkembangan teknologi yang memungkinkan penyebaran yang lebih luas dari karya-karya seni. Menurut WIPO, hak terkait adalah cara untuk melindungi "mereka yang membantu pencipta intlektual untuk

6 Tim Lindsey et al.,Hak Kekayaan Intelektual: Suatu Pengantar (Bandung: PT Alumni, 2006), hlm.102.

7 Mochamad Satyo Ariadi, Op.Cit., hlm. 3.

${ }^{8}$ Ahmad Faldi Albar, Perlindungan Hukum Penggunaan Musik Sebagai Latar Dalam Youtube MenurutundangUndang Hak Cipta,Pactum Law Journal, Vol 1 No. 04, 2018, hlm. 1-2. 
mengkomunikasikan pesan mereka dan menyebarkan karya-karyanya kepada masyarakat secara keseluruhan."9

Hak cipta dan hak terkait hanya dilanggar jika benda berwujud dari hak terkait misalnya film, cakram optik dan pita kaset yang ada hak ciptanya diperbanyak atau digandakan langsung dalam bentuk yang sama dengan benda berwujud yang merupakan ciptaan asli tanpa izin dari pemegang hak cipta. Sebagai contoh dari Cakram Optik atau pita kaset tersebut penyanyi dan para pemusik lagu yang direkam suaranya dalam CD ini dalam bentuk suara ataupun bentuk audio visual adalah yang menjadi pelaku dan mempunyai apa yang dinamakan hak terkait. Yang dimiliki oleh penyanyi sebagai pelaku hanyalah sebatas sebagai penyanyi yang menyanyikan lagu yang diperoleh izin untuk dinyanyikan oleh pencipta lagu. Penyanyi hanya terbatas mempunyai hak atas lagu yang dinyanyikannya dan hak inilah yang dinamakan sebagai hak terkait, yang dinamakan Performing Rights penyanyi. ${ }^{10}$ Biasanya yang menjadi pemegang hak cipta atas ciptaan lagu-lagu yang diperbanyak dalam bentuk $\mathrm{CD}$ atau kaset adalah produser rekaman suara, seperti Universal, Sony, Billboard dan sebagainya. Sedangkan yang menjadi pemegang hak cipta atas siaran acara-acara televisi yang dimana juga melibatkan pihak artis, aktor, penyanyi, pelawak ataupun pihak lain yang disiarkan di televisi adalah lembaga penyiaran, seperti RCTI, SCTV, TransTV, Global TV dan sebagainya.

Pengalihan itu lantas timbul perbedaan yang signifikan yang menyangkut addressat perlindungan. Bila dalam konsepsi Hak Cipta yang dilindungi adalah karya ciptanya, yaitu ciptaan yang bersifat kebendaan, sebaliknya dalam konsepsi Hak Terkait yang dilindungi adalah hak orang perorangan badan hukum atau lembaga. Fenomena yang terjadi adalah banyaknya aksi panggung (Off Air) yang menggunakan lagu, gerakan maupun tarian dari pihak yang memegang hak cipta akan tetapi dalam pelaksanaanya pemegang hak cipta tidak dapat menikmati hak ekslusif tersebut sebagai akibat masih lemah perlindungan hukum bagi pemegang hak kekayaan intelektual.

Pencipta dan pelaku merupakan bagian dari HKI maka secara langsung pencipta dan pelaku memiliki hak ekonomi dan hak moral dalam diri mereka, adapun

\footnotetext{
9 Cita Citrawinda Priapantja, Hak Kekayaan Intelektual Tantangan Masa Depan (Jakarta: Badan Penerbit Fakultas Hukum Universitas Indonesia, 2003), hlm. 84.

10 Tim Lindsey, Op.Cit., hlm. 104.
} 
pengertian hak ekonomi adalah adalah hak untuk memperoleh keuntungan ekonomi atas HKI dan dikatakan sebagai hak ekonomi karena HKI termasuk sebuah benda yang dapat dinilai dengan uang. ${ }^{11}$ Bagi pencipta atau pemegang hak cipta melakukan perbanyakan ciptaan kemudian dijual dipasaran, maka ia akan memperoleh keuntungan materi dari perbanyakan ciptaan tersebut ataupun rating televisi yang tinggi dalam siaran televise, dan bagi pelaku yang diberikan izin oleh pencipta atau pemegang hak cipta juga memperoleh keuntungan dengan cara membawakan suatu karya cipta dari sang pencipta. Sedangkan pengertian hak moral adalah hak agar ciptaan tidak diubah atau dirusak tanpa persetujuan, dan hak untuk diakui sebagai pencipta ciptaan tersebut. Hak ini tidak dapat dihilangkan dengan alasan apapun walaupun hak cipta atau hak terkait telah dialihkan, ${ }^{12}$ sedangkan hak moral dapat diartikan sebagai keharusan untuk menghormati atau menghargai karya cipta orang lain.

Sejalan dengan hak cipta sebagai hak eksklusif dan hak ekonomi pencipta/pemegang hak cipta mempunyai hak untuk memberikan izin kepada pihak lain untuk mengumumkan, memakai, atau menggandakan ciptaan dan memberikan izin tersebut tidak dapat dilepaskan dari masalah keuntungan dari penggunaan hak cipta. Pemberian izin dari pencipta/pemegang hak cipta kepada orang lain inilah yang disebut dengan lisensi. Pada dasarnya lisensi di bidang HKI tidak semata-mata hanya sekedar perbuatan pemberian izin saja, akan tetapi perbuatan tersebut menimbulkan hak-hak dan kewajiban-kewajiban yang saling bertimbal balik antara pihak satu dengan pihak yang lain. Dengan bertimbal baliknya hak-hak dan kewajiban-kewajiban inilah maka lisensi merupakan sebuah perjanjian yang mengikat mereka. Dalam ilmu hukum perjanjian yang demikian disebut dengan Perjanjian Obligatoire. Perjanjian lisensi hak cipta juga merupakan perjanjian konsensualisme, karena terjadinya perjanjian dilandasi dengan sebuah kata sepakat. ${ }^{13}$ Namun saat ini ada banyak sekali lembaga penyiaran yang menyalahi perjanjian ini, baik dalam hal live performance musik ataupun acara lain maupun perfilman.

11 Gatot Supramono, Hak Cipta dan Aspek-aspek Hukumnya, (Jakarta: Rineka Cipta, 2010), hlm. 45.

12 Haris Munandar dan Sally Sitanggang, Mengenai HAKI (Hak Kekayaan Intelektual), (Jakarta: Erlangga, 2008), hlm. 17.

13 Gatot Supramono, Op.Cit., hlm. 49. 
Implementasi masyarakat terhadap Hak Cipta dan Hak Terkait yang merupakan bagian dari Hak Atas Kekayaan Intelektual dapat dikatakan masih melakukan pelanggaran terhadap Hak Terkait, sebagaimana dilihat pada contoh kasus aransemen (cover) lagu yang dilakukan Hanin Dhiya yang mengaransemen ulang lagu yang berjudul Akad milik Band Payung Teduh, dimana Hanin Dhiya belum meminta izin untuk melakukan aransemen (cover) lagu Akad tersebut. Berdasarkan uraian di atas maka Penulis tertarik untuk mengkaji Determinasi Perlindungan Hukum Pemegang Hak Atas Neighbouring Right Dalam Undang-Undang Republik Indonesia Nomor 28 Tahun 2014 Tentang Hak Cipta, dengan batasan identifikasi masalah sebagai berikut: (1) Bagaimana Problematika Pemegang Hak Terkait Dalam Undang-Undang Republik Indonesia Nomor 28 Tahun 2014 Tentang Hak Cipta?; dan (2) Bagaimana Perlindungan Hukum Pemegang Hak atas Neighbouring RightDalam Undang-Undang Republik Indonesia Nomor 28 Tahun 2014 Tentang Hak Cipta.?

Penelitian ini menggunakan metode penelitian yuridis normatif yang bersifat deskriptif, menjabarkan penelitian secara kualitatif. Pengumpulan data sekunder yang digunakan dalam penelitian ini difokuskan pada: (a) bahan hukum primer, berupa peraturan perundang-undangan yang terkait dengan tema penelitian; dan (b) bahan hukum sekunder, berupa buku referensi dan jurnal yang terkait dengan tema penelitian dan menguraikan lebih lanjut bahan hukum primer dalam konteks teoritis.

\section{PEMBAHASAN}

\subsection{Problematika Pemegang Hak Terkait dalam Undang-Undang Republik Indonesia Nomor 28 Tahun 2014 Tentang Hak Cipta}

Hak kekayaan Intelektual (Intellectual Property Rights) adalah hak kebendaan, hak atas sesuatu benda yang bersumber dari hasil kerja otak, hasil kerja ratio. Hasil dari pekerjaan ratio manusia yang menalar. Hasil kerja itu berupa benda immaterial, benda tidak berwujud. ${ }^{14}$ Benda immaterial atau benda tidak berwujud yang berupa hak itu dapatlah dicontohkan seperti hak sewa, hak guna bangunan, hak atas kekayaan intelektual, dan lain sebagainya. Hak milik immaterial termasuk ke dalam hak-hak yang disebut dalam Pasal 499 KUHPerdata, karena itu hak milik immaterial itu sendiri dapat menjadi obyek dari suatu hak benda. Hak benda adalah hak absolute

\footnotetext{
${ }^{14}$ Haris Munandar dan Sally Sitanggang, Op. Cit, hlm. 17.
} 
atas sesuatu benda berwujud, tetapi ada hak absolute yang obyeknya bukan benda berwujud, itulah yang disebut dengan nama Hak Atas Kekayaan Intelektual (Intellectual Property Rights). ${ }^{15}$

Perlindungan hukum terhadap HAKI memiliki peranan penting, terdapat dua alasan perlunya perlindungan hukum atas kekayaan intelektual yaitu: ${ }^{16}$

1. Alasan non-ekonomis, Alasan yang bersifat non ekonomis menyatakan bahwa perlindungan hukum akan memacu mereka yang menghasilkan karya-karya intelektual tersebut terus melakukan kreatifitas intelektual. hal ini akan meningkatkan self actualization pada diri manusia. Bagi masyarakat hal ini akan berguna untuk meningkatkan perkembangan kehidupan mereka.

2. Alasan yang bersifat ekonomis, Alasan yang bersifat ekonomis adalah dengan melindungi mereka yang melahirkan karya-karya tersebut, dimana mereka yang melahirkan karya-karya tersebut mendapatkan keuntungan materiil dari karya-karyanya. Di lain pihak melindungi mereka dari adanya peniruan, pembajakan, penjiplakan maupun perbuatan curang lainnya yang dilakukan oleh orang lain atas karya-karya mereka yang berhak.

Dengan majunya teknologi, maka Hak Cipta di era digital perlu dikembangkan terlebih berkaitan dengan perlindungan hukumnya ${ }^{17}$ seperti perlindungan terhadap lagu, dan lainnya.

Selanjutnya Hak Cipta dapat diklasifikasikan ke dalam dua bagian yaitu: ${ }^{18}$
a. Hak Cipta
b. Hak Terkait (Neighbouring Rights)

Istilah Hak Terkait ada yang menerjemahkan dengan istilah hak bertetangga dengan hak cipta, ada pula yang menerjemahkan dengan istilah hak yang berkaitan atau berhubungan dengan hak cipta. Menurut O. K. Saidin, ia menggunakan istilah:

\footnotetext{
15 Mahadi, Hak Milik Immateril (Jakarta: BPHN-Bina Cipta, 1985), hlm. 5.

16 Fitriatus Shalihah dalam Aditya Taufan Nugraha, Penerapan Perlindungan Hukum Hak Cipta Terhadap Seni Batik Riau di Pekanbaru, Jurnal Selat, Mei 2014, Vol. 1 No. 2, Tanjung Pinang: Program Studi Ilmu Hukum Fakultas Ilmu Sosial dan ilmu Politik Universitas Maritim Raja Ali Haji, hlm. 85.

17 Andrew Shandy Utama, law enforcement to Copyright Infringement of Songs on the Internet Media, Fiat Justisia Vol. 12 No.3, July-September 2018, hlm. 237.

18 Artika Surniandari, Uuite Dalam Melindungi Hak Cipta Sebagai Hak Atas Kekayaan Intelektual (Hki) Dari Cybercrime, Fiat Justisia Jurnal Ilmu Hukum Volume 9 No. 4, Oktober-Desember 2015, hlm. 4
} 
"hak yang bersepadan dengan Hak Cipta oleh karena kedua hak itu (copy rights maupun neighbouring rights) adalah dua hak yang saling melekat berdampingan tetapi dapat dipisahkan satu dengan yang lainnya."19

Dalam terminologi lain Hak Terkait dirumuskan juga sebagai Rights Related to, or neighbouring on copyrights (hak yang ada kaitannya dengan, yang ada hubungannya dengan atau berdampingan dengan hak cipta). ${ }^{20}$ Dalam Hak Terkait terdapat tiga hak, yaitu:21

a. The rights of performing artist in their performances (hak penampilan artis atas tampilannya);

b. The rights producer of phonograms in their phonograms (hak produser rekaman suara atau fiksasi suara atas karya rekaman suara tersebut);

c. The rights of broadcasting organization in their radio and television broadcasts (hak lembaga penyiaran atas karya siarannya melalui radio dan televisi).

Menurut Undang-Undang Nomor 28 Tahun 2014 Tentang Hak Cipta, yang dimaksud dengan hak terkait yaitu: "Hak Terkait adalah hak yang berkaitan dengan Hak Cipta yang merupakan hak eksklusif bagi pelaku pertunjukan, produser fonogram, atau lembaga Penyiaran". ${ }^{22}$ Adapun yang dimaksud dengan hak eksklusif adalah hak yang hanya diperuntukkan bagi Pencipta, sehingga tidak ada pihak lain yang dapat memanfaatkan hak tersebut tanpa izin Pencipta. Pemegang Hak Cipta yang bukan Pencipta hanya memiliki sebagian dari hak eksklusif berupa hak ekonomi.

Berdasarkan hal itu perlu adanya perlindungan terhadap pemegang hak terkait di Indonesia dengan berkembangnya industri hiburan tanah air dari lagu, film, novel, pentas seni dan sebagainya yang membuat Indonesia menjadi salah satu peluang bagi pelaku industri untuk mendapatkan manfaat. Akan tetapi yang masih menjadi problem adalah banyaknya pelanggaran hak cipta di Indonesia.

Menurut Laporan Tahunan Special 301 yang dikeluarkan oleh Kantor Perwakilan Perdagangan Amerika Serikat (United States Trade Representatives-UTSR), Indonesia sebelum tahun 2000 merupakan satu-satunya negara di ASEAN yang masihmasuk

\footnotetext{
19 OK. Saidin, Aspek Hukum Hak Kekayaan Intelektual (Jakarta: Raja Grafindo, 2003), hlm. 14.

20 OK. Saidin, Ibid, hlm. 133.

${ }^{21}$ International Bureau of WIPO, International Protection of Copyrights and NeighbouringRights,WIPO/CNR/ABU/93/2.

22 Pasal 1 angka 5 Undang-Undang Nomor 28 Tahun 2014 tentang Hak Cipta.
} 
kategori priority watch list. Priority watchlist artinya pelanggaran atas HAKI masuk kategori yang berat sehingga Amerika Serikatmelakukan prioritas pengawasan dengan mitra dagangnya. ${ }^{23}$

Tahun 2007 hingga 2008, Indonesia sempat dalam kategori watch list. Watch list artinya negara yang masuk kategoriini cukup diawasi karena tingkat pelanggaranHAKI dianggap masih belum terlalu berat. Pada tahun 2009, Indonesia kembali diturunkandan masuk kategori priority watch list 11 hingga tahun $2014 .^{24}$ Problematika kontemporer yang berkaitan dengan hak terkait adalah menyanyikan kembali sebuah lagu (Cover) yang di komersialisasikan lewat Youtube biasanya lagu yang di-cover adalah lagu-lagu yang sedang meledak di pasaran. Mengapa dikatakan dikomersialisasikan? Karena penyanyi yang melakukan cover lagu akan mendapatkan pendapatkan dari jumlah penonton maupun iklan.

Salah satu kasus yang ramai di dunia maya saat ini yaitu aransemen (cover) lagu yang dilakukan Hanin Dhiya yang mengaransemen ulang lagu yang berjudul Akad milik Band Payung Teduh. Pihak manajemen Payung Teduh menjelaskan bahwa aransemen (cover) lagu yang dilakukan Hanin Dhiya belum meminta izin untuk melakukan aransemen (cover) lagu Akad tersebut. Sedangkan pihak manajemen Hanin Dhiya menjelaskan bahwa pihaknya belum pernah menyampaikan izin secara tertulis atau secara resmi dan hanya dilakukan secara lisan melalui seseorang yang dekat dengan payung teduh. Akan tetapi, pihak manajemen Hanin Dhiya tidak memastikan kembali apakah izin tersebut sampai kepada manajemen Payung Teduh atau tidak. ${ }^{25}$

Hak Terkait dalam hukum di Indonesia pengaturannya masih ditumpangkan dengan pengaturan Hak Cipta. Namun jika ditelusuri lebih lanjut Hak Terkait itu lahir dari adanya Hak Cipta induk, misalnya liputan pertandingan sepak bola adalah Hak Cipta sinematografi, tetapi untuk penyiarannya di televisi yakni berupa hak siaran adalah Hak Terkait. Keduanya masih merupakan satu kesatuan, tetapi dapat

23 Sophar Maru Hutagalung, Hak Cipta Kedudukan \&Peranannya dalam Pembangunan, Jakarta: Sinar Grafika,2012, hlm. 7.

24 Sophar Maru Hutagalung, Ibid.

25DwiRizki,http://www.tribunnews.com/seleb/2017/10/04/minta-maaf-hanin-dhiya-beberkan-soal-izin-coverlagu-akad-payung-teduh-ini-yang-telah-dilakukannya?page=2, akses tanggal 21 Mei 2019. 
dipisahkan. Adanya Hak Terkait selalu diikuti dengan adanya Hak Cipta, namun sebaliknya adanya Hak Cipta tidak mengharuskan adanya Hak Terkait. ${ }^{26}$

Seorang artis memiliki hak untuk melarang orang lain yang tanpa persetujuannya membuat atau memperbanyak atau menyiarkan rekaman suara dan atau gambar dari pertunjukannya untuk tujuan komersil. Hak yang melekat pada artis tersebut selain Hak Cipta, juga Hak Terkait. Yang termasuk Hak Cipta adalah hak atas karya rekaman suara, sedangkan Hak Terkaitnya adalah hak atas penampilannya. Hak atas penampilannya itu dapat berwujud seperti video clip (penggalan-penggalan film atau sinematografi). ${ }^{27}$

\subsection{Perlindungan Hukum Pemegang Hak atas Neighbouring Right dalam Undang-Undang Republik Indonesia Nomor 28 Tahun 2014 Tentang Hak Cipta}

Perlindungan Hak Terkait selain diatur dalam undang-undang, saat ini pengaturannya terdapat juga dalam kaidah hukum Internasional, yaitu: ${ }^{28}$

1. Rome Convention for the Protection of Performers, Producers of Phonograms and Broadcasting Organization (1961);

2. Geneva Convention for the Protection of Producers of Phonograms against Unauthorized Duplication of Their Phonograms; and

3. Brussels Convention Relative to the Distribution of Programme Carring Signal Transmitted by Satellite.

Sedangkan dalam hukum Indonesia pengaturannya tidak disebutkan secara rinci dalam satu peraturan khusus tetapi dalam Undang-Undang Nomor 28 Tahun 2014 Tentang Hak Cipta.Perlindungan hukum yang diberikan kepada pemilik Hak Terkait berdasarkan Undang-Undang Hak Cipta 2014 yakni:

1. Pengaturan mengenai pencatatan/ pendaftaran produk hak terkait.

2. Pengaturan pengguna hak terkait bagi yang memanfaatkan hak terkait untuk kepentingan komersial harus membayar royalti kepada pemilik hak terkait melalui Lembaga Manajemen Kolektif.

26 OK. Saidin,Op. Cit, hlm. 14.

27 OK. Saidin, Ibid.

28 Bandingkan, Niken Prasetyawati, Perlindungan Hak Cipta Dalam Transaksi Dagang Internasional, Jurnal Sosial Humaniora, Vol 4 No.1, Juni 2011, hlm. 7-8. 
3. Memberikan ancaman pidana bagi pelanggaran terhadap hak ekonomi pemilik Hak Terkait sebagaimana diatur dalam UU Hak Cipta.

Dalam Undang-Undang Hak Cipta Nomor 28 Tahun 2014 terdapat larangan mengenai penyebaran konten karya siaran tanpa izin dengan tujuan komersial. Undang-undang hak cipta mengkategorikan perbuatan-perbuatan yang dianggap tidak melanggar hak cipta atau hak terkait apabila: ${ }^{29}$

1. Penyebarluasan konten hak cipta dan/atau hak terkait melalui media teknologi informasi ${ }^{30}$ dan komunikasi tidak bersifat komersial.

2. Dalam hal pemanfaatan ciptaan dan/atau produk hak terkait secara komersial oleh pengguna sepanjang pengguna telah melakukan dan memenuhi kewajiban sesuai perjanjian dengan LMK.

3. Jika mencantumkan sumbernya.

Rome Convention for the Protection of Performers, Producers of Phonograms and Broadcasting Organization adalah suatu konvensi internasional yang dirujuk oleh TRIPs art 14 (6) dalam hubungan dengan hak pelaku (performers), produser fonogram (rekaman suara) dan lembaga penyiaran. Rome Convention disepakati pada tahun 1961 dan hingga sekarang tercatat ada 69 negara anggota per 15 Juli 2002, tidak termasuk Indonesia. ${ }^{31}$

Pasal 3 dari Rome Convention tersebut memberikan definisi: ${ }^{32}$

1. Performers adalah aktor, penyanyi, musisi, penari dan orang lain yang beraksi, menyanyi, mempertunjukkan karya kesasteraan atau artistik.

2. Phonogram adalah fiksasi oral suara dari pertunjukan.

3. Produser Phonogram adalah orang-orang yang atau badan hukum yang pertama-tama membuat suara dari pertunjukkan atau suara lainnya.

4. Publikasi berarti menyerahkan copy dari Phonogram kepada publik dalam jumlah yang layak.

5. Reproduksi berarti membuat copy-copy dari fiksasi.

\footnotetext{
29 OK. Saidin, Op. Cit, hlm. 139.

30 Analisis informasi akan mengungkapkan banyak tentang kebiasaan dan gaya hidup individu yang dapat digunakan sebagai dasar untuk menilai bahwa informasi yang diberikan apakah sudah benar atau tidak . Bandingkan, Lan J. Lloyd, Informatian Technology Law, Oxford University Press: New York, 2010, hlm. 6

31 Mochamad Satyo Ariadi, Op.Cit.,hlm. 34.

32 Chairul Anwar, Hak Cipta Pelanggaran Hak Cipta \& Perundang-undangan Terbaru Hak Cipta Indonesia (Jakarta: Novindo Pustaka Mandiri, 1999) hlm. 25.
} 
6. Broadcasting berarti transmisi dengan wireless untuk penerimaan publik atas suara atau latar suara.

7. Rebroadcasting berarti penyiaran yang simultan oleh satu organisasi penyiaran dan penyiaran dari organisasi penyiaran lainnya.

Pasal-pasal yang penting dari Konvensi Roma 1961 adalah Pasal 10 yang sudah menyatakan bahwa produser dari phonogram akan menikmati hak untuk menguasakan atau melarang reproduksi langsung atau tidak langsung dari phonogram mereka. Dan juga dalam Pasal 13 dari Konvensi Roma 1961 menyatakan bahwa organisasi penyiaran akan menikmati hak untuk menguasakan atau melarang: ${ }^{33}$

1. Penyiaran ulang dari siarannya.

2. Fiksasi dari penyiaran.

3. Reproduksi:

a. Dari fiksasi yang dilakukan tanpa persetujuan mereka dari penyiaran mereka

b. Dari fiksasi yang dibuat sehubungan dengan ketentuan-ketentuan Pasal 15 dan siaran mereka, kalau reproduksi dibuat untuk maksud berbeda dari hal-hal yang telah ditentukan.

4. Komunikasi kepada publik dari siaran televisi mereka, kalau komunikasi tersebut dibuat ditempat-tempat yang mempunyai akses terhadap pembayaran dari fee entrance, yang hal ini dapat diatur oleh hukum dalam negeri dari negara yang bersangkutan

Dalam ketentuan konvensi ini, ada yang menyebutkan bahwa pemberian jaminan perlindungan tersebut didefinisikan sesuai dengan kebutuhan nasional masing-masing negara anggota, yang berarti dapat diambil kesimpulan bahwa bentuk-bentuk jaminan perlindungan tersebut dapat saja berbeda-beda diantara sesama negara anggota. Untuk lebih jelasnya hal ini dapat dilihat dalam Pasal 2 konvensi ini yang terjemahannya berbunyi:

Perlindungan yang diberikan oleh konvensi, didefinisikan sesuai dengan kebutuhan nasional.

${ }^{33}$ Chairul Anwar, Ibid, hlm. 26. 
1. Demi kegunaan konvensi ini, kebutuhan nasional berarti kebutuhan yang sesuai dengan hukum lokal yang berlaku dimana ada disebut tentang perlindungan yang diberikan:

a. Bagi pemain nasional yang penampilannya mengambil tempat, rekaman atau pengubahan pertama dilaksanakan di wilayah hukum yang berlaku.

b. Bagi produser rekaman nasional, yang melakukan rekaman awal dan publikasi awal di wilayah hukumnya.

c. Bagi organisasi penyiaran yang mempunyai kantor diwilayah hukumnya, yang melakukan penyiaran dari transmisi yang terletak di wilayah hukumnya.

2. Perlakuan nasional secara subjektif berupa jaminan perlindungan secara khusus serta pembatasan-pembatasan terhadap keadaan yang memaksa seperti pada konvensi ini. ${ }^{34}$

Geneva Convention for the Protection of Producers of Phonograms against Unauthorized Duplication of Their Phonograms mengatur tentang hak produser rekaman dan Brussels Convention Relative to the Distribution of Programme Carring Signal Transmitted by Satellite menitikberatkan pada pengaturan tentang distribusi program siaran yang menggunakan jaringan transmisi satelit. Produser rekaman suara berarti orang yang menurut ketentuan hukum untuk pertama kalinya memfiksasikan suara orang lain dalam bentuk karya rekaman suara. Seorang produser berhak mendapat perlindungan hukum terhadap karya rekaman suara orang lain yang merupakan hasil kerjanya, bilamana hasil karya rekaman itu ditayangkan ulang oleh pihak lain untuk tujuan komersil.

Berikut ini akan diuraikan tentang hak-hak pelaku, produser, dan lembaga penyiaran.

1) Hak Pelaku atas Tampilannya ${ }^{35}$

Istilah pelaku digunakan untuk memperluas cakupan pengertian performers yang tidak hanya terbatas pada ruang lingkup artis semata-mata tetapi juga mencakup seluruh aktivitas manusia yang menampilkan kebolehannya di depan publik, yang tidak hanya terbatas pada penampilan yang berlatar

\footnotetext{
34 OK. Saidin, Op.Cit.,hlm. 215
}

35 OK. Saidin, Ibid. 
belakang kesenian dan kesusastraan. Di Indonesia untuk hak-hak para pencipta lagu, musisi dan penyanyi untuk meneerima pembayaran royalty dipegang oleh Yayasan Karya Cipta Indonesia (YKCI). Royalti itu berasal dari pemutaran lagu-lagu di berbagai tempat hiburan yang bersifat komersil. YKCI hanya menagih royalty yang berasal dari anggota yayasan. Royalti itu dibayarkan kepada pencipta lagu, musisi dan penyanyi dengan hitungan persentase tertentu. ${ }^{36}$

Persoalan yang dihadapi yakni sikap dan pandangan para pengusaha hiburan yang menganggap bahwa memutar atau menyanyikan lagu-lagu (yang dilindungi hak cipta atau neighbouring rights) orang lain tidak diwajibkan membayar royalti, padahal dalam aktivitas mereka, pengusaha tersebut menjual hiburan dengan memanfaatkan karya cipta orang lain.

Perlindungan yang sama juga harus diberikan kepada pelaku lain, selain penyanyi yakni pembawa acara, pemandu acara, pembaca berita, para atlit, dan lain-lain. Maka sudah sepantasnya sebagian dari keuntungan itu diserahkan kepada pemegang neighbouring rights. Dengan demikian kreativitas akan tumbuh dengan pesat, dan inilah salah satu tujuan dari perlindungan hukum neighbouring rights.

2) Hak Produser Rekaman ${ }^{37}$

Produser rekaman suara biasanya mendapatkan hak untuk merekam suara dari para penyanyi atau musisi. Hak itu dapat diperoleh atas persetujuan pencipta atau orang yang menerima hak dari pencipta. Persetujuan itu dapat berupa lisensi.

Produser juga mengeluarkan dana yang tidak sedikit untuk biaya produksi. Produser tidak hanya berhak mendapat keuntungan dari penjualan kaset atau $\mathrm{CD}$, tetapi berhak juga atas royalti manakala kaset atau CD itu dikumandangkan di tempat-tempat yang bersifat komersil.

3) Hak Lembaga Penyiaran ${ }^{38}$

Dalam kaitannya dengan perlindungan neighbouring rights, radio dan televisi dapat menyiarkan hasil rekaman dengan membayar royalti kepada pemegang

\footnotetext{
36 OK. Saidin, Ibid, hlm.139.

37 J.B. Wahyudi, Dasar-Dasar manajemen Penyiaran, Gramedia Pustaka Utama, Jakarta, 1994, hlm. 40.

38 J.B. Wahyudi, Ibid.
} 
hak eksklusif. Hak ekslusif itu adalah lembaga penyiaran pertama atau yang untuk pertama kalinya menyiarkan acara itu.

Adapun hak-hak yang dimiliki oleh lembaga siaran tersebut adalah:

a. Moral Rights, merupakan hak dari performers untuk disebutkan namanya dalam kaitan dengan pertunjukan mereka dan hak untuk menolak kerugian yang ditimbulkan akibat dari pertunjukan mereka.

b. Exclusive Rights, dalam hal reproduksi, distribusi, rental dan rekaman suara secara online terhadap pertunjukan mereka.

c. Hak untuk memperoleh pembayaran yang wajar dari siaran dan komunikasi kepada khalayak dari penanyangan ulang siaran mereka.

Bila diamati dan dicermati masalah moral rights atau hak moral, kita akan segera mengetahui bahwa hak moral merupakan hak dasar yang dimiliki oleh performers (artis, penyanyi, pemusik dan orang-orang yang berakting, berpidato, mendeklamasikan, memainkan maupun menampilkan karya seni dan kesusastraan dan cerita rakyat) ${ }^{39}$ untuk disebutkan namanya. Dalam penampilan sebuah lagu di radio atau televisi penyiar radio wajib menyebutkan nama penyanyi dan penciptanya begitu juga musisinya. Performers atau pemegang hak mempunyai hak untuk mendapatkan pembayaran yang wajar dari hasil siaran yang disiarkan oleh lembagalembaga penyiaran. Hal ini merupakan hal yang wajar karena lembaga siaran ini mendapatkan keuntungan atau fee dari produsen-produsen yang produknya ditawarkan melalui radio atau televise tersebut dalam bentuk iklan. Inilah wujud dari Property Rights yang dimiliki oleh performers.

Pembayaran royalti adalah merupakan salah satu bentuk implementasi ditegakkannya pengakuan atas hak cipta secara umum dan secara khusus penegakan hak atas Neighboring Rights di kalangan lembaga penyiaran. Hal ini juga tak lain adalah sebagai konsekuensi berlakunya ketentuan TRIPS (Trade Related Aspects of Intellectual Property Rights) di Indonesia, dimana Indonesia adalah salah satu penandatangan Konvensi Roma yang di dalamnya mengatur ketentuan tentang Neighboring Rights ini.

39 WIPO Performances and Phonograms Treaty, Artcle 2 (a). 


\section{PENUTUP}

\subsection{Simpulan}

Dalam hukum Indonesia perlindungan Hak Terkait tidak disebutkan secara rinci dalam satu peraturan khusus tetapi melalui peraturan perundang-undangan yaitu Undang-Undang Nomor 28 Tahun 2014 tentang Hak Cipta, berupa Pengaturan mengenai pencatatan/pendaftaran produk Hak Terkait, dan Pengaturan pengguna hak terkait bagi yang memanfaatkan hak terkait untuk kepentingan komersial harus membayar royalti kepada pemilik Hak Terkait melalui Lembaga Manajemen Kolektif, dan memberikan ancaman pidana bagi pelanggaran terhadap hak ekonomi pemilik Hak Terkait sebagaimana diatur dalam UU Hak Cipta.

\subsection{Saran}

Agar perkembangan mengenai Hak Terkait dengan Hak Cipta makin pesat terutama di bidang perlindungan hukumnya, hendaknya dilakukan sosialisasi kepada masyarakat luas terutama masyarakat media agar masyarakat memahami seperti apa dan bagaimana konsep dari Hak Terkait dengan Hak Cipta. Para penegak hukum diharapkan agar dalam menangani perkara pelanggaran Hak Terkait kiranya mempergunakan wewenang yang diberikan undang-undang, hendaknya hukuman yang diberikan benar-benar setimpal dengan pelanggaran yang dilakukan. Hal ini bertujuan untuk mengurangi berbagai bentuk pelanggaran yang dapat merugikan Pelaku Industri Hiburan.

\section{DAFTAR PUSTAKA}

Alfons, Maria. "Implementasi Hak Kekayaan Intelektual dalam Perspektif Negara Hukum." Jurnal Legislasi Indonesia Vol. 14 (September 2017).

Brussels Convention Relative to the Distribution of Programme Carring Signal Transmitted by Satellite.

Febriharini, Mahmuda Pancawisma. "Eksistensi Hak Atas Kekayaan Intelektual Terhadap Hukum Siber." Jurnal Ilmiah (UNTAG Semarang), 2016.

Geneva Convention for the Protection of Producers of Phonograms against Unauthorized Duplication of Their Phonograms.

Hutagulung, Sophar Maru. Hak Cipta Kedudukan \& Peranannya dalam Pembangunan. Jakarta: Sinar Grafika, 2012.

Lloyd, Lan J. Information Technology Law. New York: Oxford University Press, 2010. 
Mahadi. Hak Milik Immateriil. Jakarta: BPHN-Bina Cipta, 1985.

Munandar, Haris, and Sally Sitanggang. Mengenai HAKI (Hak Kekayaan Intelektual). Jakarta: Erlangga, 2008.

Nugraha, Aditya Taufan. "Penerapan Perlindungan Hukum hak Cipta Terhadap Seni Batik di Pekanbaru." Jurnal Selat, 2017.

Prasetyawati, Niken. "Perlindungan Hak Cipta dalam Transaksi Dagang Internasional." Jurnal Sosial Humaniora Vol. 4 (Juni 2011).

Priapantja, Cita itrawinda. Hak Kekayaan Intelektual Tantangan Masa Depan. Jakarta: Badan Penerbit Fakultas Hukum Indonesia, 2003.Ristyan, Edwita. "Perlindungan Hak Terkait Terhadap Karya Siaran Skysports yang Dipublikasikan Melalui Situs Internet." Skripsi FH Atma Jaya Yogyakarta, 2017.

$\begin{array}{lllll}\text { Rizki, } & \text { Dwi. } & \text { Tribun } & \text { Mews. }\end{array}$ http://www.tribunnews.cpm/seleb/2017/10/04/minta-maaf-hanin-dhiyabeberkan-soal-izin-cover-lagu-akad-payung-teduh-ini-yang-telahdilakukannya?page $=2$.

Rome Convention for the Protection of Performers, Producers of Phonograms and Broadcasting Organization.

Rongiyati, Sulasi. "Perlindungan Hukum Hak Kekayaan Intelektual Pada Produk Ekonomi Kreatif." Jurnal Negara Hukum Vo. 9 (Juni 2018).

Saidin, OK. ASpek Hukum Kekayaan Intelektual. Jakarta: RajaGrafindo, 2003.

Supramono, Gatot. Hak Cipta dan Aspek-Aspek Hukumnya. Jakarta: Rineka Cipta, 2010.

Surniandari, Artika. "UU ITE Dalam Melindungi Hak Cipta Sebagai Hak Atas Kekayaan Intelektual (HKI) Dari Cybercrime." Fiat Justitia Jurnal Ilmu Hukum 9 (OktoberDesember 2015).

Tim, Lindsey. Hak Kekayaan Intelektual: Suatu Pengantar. Bandung: Alumni, 2006.

Undang-Undang Nomor 28 Tahun 2014." tentang Hak Cipta. n.d.

Utama, Andrew Shandy. "Law Enforcement to Copyright Infringement of Songs on the Internet Media." Fiat Justisia, 2018.

Wahyudi, J.B. Dasar-Dasar Manajemen Penyiaran. Jakarta: Gramedia Pustaka Utama, 1994.

WIPO Perfomances and Phonograms Treaty. 